\title{
Students' Needs for TOEFL Preparation Course at University
}

\author{
Rahmi Eka Putri ${ }^{1)}$, Hermawati Syarif ${ }^{2)}$ \\ ${ }^{1), 2)}$ Universitas Negeri Padang \\ email: amethyst.himekawaii@gmail.com ${ }^{1}, \underline{\text { hermawati_sy@yahoo.com }}{ }^{2}$
}

\begin{abstract}
This study aimed to identify students' needs in the TOEFL Preparation course at university. This descriptive research was conducted on thirty first-semester students and the lecturer at Universitas Riau. The instruments were a needs analysis questionnaire for the students and an interview guideline for the lecturer. The results revealed that (1) Most of the students' abilities were at the basic level; (2) Students took TOEFL Preparation course for several reasons such as to help them get a scholarship and as one of the requirements to finish their study; (3) Students preferred to learn through the teacher-centered method and doing more TOEFL exercises; (4) The lecturer should provide them various examples of TOEFL tests; and (5) The time for having TOEFL Preparation course needed to be extended. Overall, this research implied the need for a newly designed syllabus that could fulfil the students' needs and could decrease their obstacles in learning TOEFL so that the students' ability improved significantly.
\end{abstract}

Keywords: needs analysis, TOEFL course, university students

\section{Introduction}

As a global language, English has touched numerous aspects of life, including education, which has established it as a lingua franca (common language) in international relations. English proficiency is viewed as critical in academic settings, to the point where higher education has decided to use English language proficiency tests, such as the TOEFL (Test of English as a Foreign Language), IELTS (International English Language Testing System), and TOEIC (Test of English for International Communication), to determine students' eligibility, particularly for admission and exit requirements (Crystal, 2003; Ng, 2007). In the case of the TOEFL, Roberts (2000) and Vu \& Vu (2013) assert that this exam has been widely used to assess the English language proficiency of international students wishing to study in English-speaking nations such as Canada and the United States. TOEFL exam scores play a key influence in determining whether a potential non-English speaker can be admitted to institutions in those nations $(\mathrm{Vu} \& \mathrm{Vu}, 2013)$. This is also true in Indonesia, where many universities require students to take the TOEFL test to assess their English proficiency and to determine their admission or graduation status (Ermawan, Arifin \& Salam, 2014; Hambali, 2008; Mahmud, 2014; Samad, Jannah, \& Fitriani, 2017).

The TOEFL administered by universities in Indonesia is termed TOEFL Prediction or TOEFLEquivalent, and it follows a framework comparable to the TOEFL ITP (Institutional Testing Program) (Mahmud, 2014). The TOEFL ITP is popular in Indonesia and is recommended by universities and institutions for a variety of reasons: accessibility to learning resources, availability of approved test locations, and an inexpensive price (Hambali, 2008). Nonetheless, Mahmud (2014) concludes that colleges attempted to offer the TOEFL Prediction at a significantly reduced price to their students, claiming that the test result would be utilized exclusively for internal purposes. Despite its local use, TOEFL Prediction has the same high-stakes objective as the official TOEFL: to determine students' 
futures (Suryaningsih, 2014), such as eligibility for undergraduate thesis examination; hence, students work diligently to achieve the requisite minimum test results.

However, reaching the target TOEFL score becomes an obstacle for most students. There is, nevertheless, a significant gap between expectations and reality. There are still a significant number of English as Foreign Language (EFL) students who do not achieve satisfactory marks on the ITP test. The majority of them agreed that one of the most difficult parts of the ITP test was the second section, which deals with written structure and phrases. Hambali's (2008) research found that students continue to face numerous hurdles when answering the ITP part two test. These difficulties include recognizing the verb, establishing the proper word order for the subject and verb in the noun phrase, and establishing the derivation and function of words. After that, Ananda (2016) stresses that a significant area of concern for ITP test students is part 2, Structure and Written Expressions; hence, students frequently feel pushed by this section. Additionally, they claimed that grammar issues are viewed as a barrier to students achieving high TOEFL scores, which is one of the requirements for admission to higher education institutions both in Indonesia and overseas. In line with this, Mahmud (2014) discovered that many of the respondents had significant difficulties answering the structural and written expressions in his study.

Considering the importance of TOEFL, Universitas Riau has included TOEFL as one of the compulsory courses that should be taken by all students at the first semester. The students need to reach a minimum of 450 of the TOEFL prediction score for non-English Department students and a minimum of 500 for English Department students to complete one of the thesis examination requirements. To reach this target, Universitas Riau sets this course to be conducted in the first semester for fourteen meetings in which each meeting lasts for 2 credits. It indicates that all students must take this course to help them reach the targeted score as well as to improve their English ability in general.

However, TOEFL Preparation course in this university seems to be problematic since it was found that many students still could not achieve the targeted score at the end of the course. It was found that the course provided this time did not really meet the students' needs in TOEFL Preparations course. Thus, it was necessary to investigate the current situations in the TOEFL Preparation class in order to reveal the learning needs and target needs in TOEFL Preparation course.

The main purpose of this study was to investigate a suitable syllabus for TOEFL Preparation course, especially at Universitas Riau. To reach this purpose, the needs analysis conducted in this study aimed to identify problems faced students and lecturers in TOEFL Preparation course as well as the students' needs and expectation in TOEFL Preparation Course at Universitas Riau.

\section{Needs Analysis}

Needs analysis is the phase of analysis during which numerous perspectives on a task are gathered in order to ascertain the source of a gap between ideal and actual performance. Nation and Macalister (2010) reaffirm this, stating that needs analysis is the technique for determining what the learner already knows and what they need to know. According to this definition, needs analysis is an attempt to ascertain the nature of the issue that resulted in the actual performance falling short of the ideal performance. By identifying the gap, a needs analysis is supposed to provide information for curriculum creation.

Moreover, Graves (2004) defines need analysis (NA) as something that instructors can observe and do as part of their instruction. The developer will determine the students' needs and the type of teaching and learning materials that will be taught to them. As a result, it is critical to identify and analyze both target and learning needs. Additionally, need analysis has been defined by a variety of schools, and comprehending these definitions aids in the further analysis of the subject at hand. In general, need analysis is described as a specific foundation for the future development of a certain set of students' academic activities. With a particular emphasis on language-related needs in terms of language programs, the needs analysis is explained via the lens of curriculum creation (Bosher, \& Smalkoski, 2002; Chaudron, et.al., 2005). 
Furthermore, Richards (2001) describes in detail how need analysis can be utilized for a variety of different goals. Several of them are to ascertain what language skills a learner requires to perform a specific role, such as sales manager, tour guide, or university student, to ascertain whether an existing course adequately addresses the needs of potential students, to ascertain which students from a group are most in need of training in particular language skills, to ascertain whether a reference group believes a change in direction is necessary, and to ascertain whether a gap exists between what a reference group believes is important.

Furthermore, Hutchinson and Waters (1987) divide needs into the target needs and learning needs. Target needs are what the learners need to do in the target situation while learning needs refer to what the learner needs to do in order to learn. The target needs can be divided into necessities, lack, and wants. Necessities are related to the demand of the target situation, what the learner must know in order to function effectively in the target situation (Hutchinson, \& Waters, 1987). Moreover, Nation and Macalister (2010) use the term task to replace the word situation in defining necessities. Then, lack is defined as the gap existed between actual performance and target performance (Hutchinson, \& Waters, 1987), which focuses on target proficiency and actual proficiency. Similarly, Nation and Macalister (2010) propose that lack is what the learners have known at present. The focus is only on what the learner actual proficiency at present. The information of lack gathered then is used for determining what necessities which have not been achieved by the learners. Therefore, the information regarding to the Lack can be gathered from the students' task analysis or self-rating. At last, Wants refers to what the learners wants to learn based on their view which will help them for their target situation (Nation, \& Macalister, 2010). Wants represent what the students want in the learning to meet the target situation. Thus, the students' wants are also able to be used as considered information for curriculum development activities. The information can be gathered directly from the students.

Need analysis is an effective technique for determining students' requirements and assisting in the implementation of educational strategies. Nunan (1989) asserts that information obtained from NA may be used for the following purposes: (a) NA can be used to establish the course's objectives and guide content selection; (b) It can be used by the teacher to modify the syllabus and methodology in order to minimize the gap between teachers' and students' expectations; and (c) It can be used to identify the gap between teachers' and students' expected teaching and learning approaches.

\section{An Overview of Test}

A test is described as a procedure for determining an individual's capability, knowledge, or performance in a given field (Brown, 2004). In general, the term "test" refers to examination in contemporary educational contexts, a literal meaning derived from the Latin word "testum," which refers to a bowl typically used to analyze objects (Webster, 2017). When a test is used to evaluate a learner's ability or performance, it generates data, or scores, that enable test developers to comprehend the learner's competence (Brown, 2004; Zucker, 2003). Thus, a test must be well-designed in order to accurately reflect a test taker's capability.

However, ideally, a test would be created using the following criteria: feasibility, validity, reliability, authenticity, and washback (Brown, 2004; Zucker, 2003). A test is considered practical if it offers an affordable price, simple administration, adequate test time, and simple scoring; a test is considered valid if it is capable of measuring what it is intended to measure; a test is considered reliable if the results are consistent across different test times; an authentic test includes questions that are contextual, relevant, and close to real life; and washback refers to the test's impact (Brown, 2001, 2004; Richards, 2001; Zucker, 2003).

TOEFL is a standardized language test that is generally referred to as an Educational Testing Service (ETS) product. It is used to assess the competency of non-English speakers (Stricker, \& Attali, 2010). TOEFL is extremely popular in higher education, as indicated by the fact that over 10,000 universities 
from more than 150 countries employ TOEFL results in their admissions decision process (Educational Testing Service (ETS), 2019b).

TOEFL was developed in 1963 by the National Council on the Testing of English as a Foreign Language, a non-profit organization comprised of more than 30 governmental and private entities (Stricker, \& Attali, 2010; Wainer, \& Lukhele, 1997). ETS acquired TOEFL in 1965, along with the College Board, and was later joined by the Graduate Record Examinatios in 1973. In 1975, ETS was appointed exclusive administrator of TOEFL by the TOEFL Board (Spolsky as cited in Roberts, 2000; Stricker, \& Attali, 2010). Since its inception in 1963, TOEFL has evolved through numerous formats, including paper-based testing (PBT) in 1995, computer-based testing (CBT) in 1998, and internet-based testing (iBT) in 2005 (Roberts, 2000; Stricker, \& Attali, 2010; Vu, \& Vu, 2013). Additionally, ETS develops TOEFL ITP in the format of its PBT predecessor, with the intent of using it exclusively for placement or evaluation in local/institutional settings (Educational Testing Service (ETS), 2019b).

The TOEFL ITP score is mapped into the Common European Framework of Reference for Language (CEFR) which is measured at four different levels, namely A2, B1, B2 and C1. level A1 means that the test takers are basic users who have elementary level of English proficiency while level B1 indicates that the person have intermediate level of ability or can be classified as an independent user. Then, level B2 implies that the test takers are also classified as independent users, but they are already at upper intermediate level. Finally, level $\mathrm{C} 1$ means that the test takers possess effective operational proficiency, or they are considered as proficient users (Educational Testing Service (ETS), 2019a).

In this study, the TOEFL Prediction follows the TOEFL ITP format, which consists of three subbatteries: Listening Comprehension, Structure and Written Expression, and Reading Comprehension. Following the pattern of TOEFL ITP, the questions in TOEFL Prediction are multiple-choice, with 50 items in the listening portion, 40 things in the structure section, and 50 items in the reading section. The test lasts around 115 minutes and yields a score between 310 and 677 (Educational Testing Service (ETS), 2019a).

Messick, as mentioned in Netta and Trisnawati (2019), defines test preparation as any intervention process designed particularly to increase test scores, whether by enhancing the skills tested by the exam or by enhancing test-taking skills, or both. According to this concept, Liu (2014) comments that if a test taker wishes to increase his or her test scores, he or she may engage in any form of activity before to the test in order to be fully prepared. To this goal, test preparation tactics may generally be divided into three categories: (1) test-taking orientation, which entails familiarity with the test format and procedure; (2) coaching, which entails an intensive course; and (3) training, which entails strengthening cognitive skills (Anastasi, as cited in Liu, 2014).

Numerous studies have been conducted on test preparation tactics. Roberts (2000) examined how 14 Korean English language learners prepared for the official TOEFL. His study discovered that learners attempted to enhance their TOEFL scores on their own by using many TOEFL preparation books or manuals available in bookstores (e.g., Barron's How to Prepare for the TOEFL, Cambridge Preparation for the TOEFL Test). These instructions are meant to familiarize learners with TOEFL-style questions and to allow them to practice the example examinations (Roberts, 2000). Then, Liu (2014) conducted a survey of 14,593 Chinese test takers who took the TOEFL iBT. Her findings indicated that the two most often used tactics for test preparation were listening to English programs and watching English films.

Test preparation may also include training at TOEFL preparation classes in addition to self-study. Masfufah (2018) assessed 11 students enrolled in a TOEFL preparation course at a private college in Indonesia. The majority of her responders stated that the preparatory lesson aided them in improving their English proficiency for the test. Additionally, Ma and Cheng (2015) examined a group of Chinese students who enrolled in a TOEFL iBT preparation course prior to sitting for the exam. The students felt that the preparation course was effective in terms of test preparation because it enabled them to quickly become familiar with the exam structure and gain satisfactory scores. A TOEFL online course is another option for preparation, as demonstrated in a study by Sudrajat and Astuti (2018) who collected data from 
505 students enrolled in an online preparation course. The majority of respondents claimed that they obtained adequate desire and confidence in order to study the necessary English grammar for the TOEFL test.

\section{Methods}

This study utilized a descriptive qualitative study method. The participants of this research were 70 first-semester students from non-English Department who took the TOEFL Preparation course in the Academic Year 2021/2022 and one lecturer who taught TOEFL Preparation course. The participants were selected by random sampling. The intended data were collected through a questionnaire and interview guidelines which were designed following the needs analysis indicators from Hutchinson and Waters (1987). The questionnaire was distributed to the students while the interview was conducted to the lecturer. Data from the questionnaire were then analyzed by the formula from Sudjana (2002) and classified into low, medium, and high. Then, data from the interview were used to support the results from the questionnaire.

\section{Results and Discussion}

TOEFL Preparation course at Universitas Riau was designed to enable students to master English proficiency in general and to achieve the targeted score as a requirement for graduation in specific. Analyzing the needs means the analysis of students' present situation, students' ability, and difficulties TOEFL Preparation course, students' needs, the existing materials, the objectives of the course, as well as the identification of the result of analysis. Data obtained for the needs analysis in this study were grouped into (a) course objectives, (b) learning methods, (c) available sources, (d) students' characteristics, and (e) setting of the course. Findings of this study are discussed below.

\section{Learning Objectives}

The result of learning objectives is displayed in Table 1.

Table 1. Learning Objectives

\begin{tabular}{llcc}
\hline No. & The objective of TOEFL Preparation & \multicolumn{1}{c}{$\begin{array}{c}\text { Percentage } \\
\text { course }\end{array}$} & Category \\
\hline 1 & $\begin{array}{l}\text { TOEFL is one of the requirements for } \\
\text { graduation. }\end{array}$ & $100 \%$ & High \\
2 & $\begin{array}{l}\text { To help students improve their English } \\
\text { ability. }\end{array}$ & $90.4 \%$ & High \\
3 & To help students to get a scholarship. & $89.3 \%$ & High \\
\hline
\end{tabular}

Table 1 demonstrated that students took TOEFL Preparation course for three reasons. The first and the main reason was that having the targeted TOEFL score was one of the requirements for graduation. It is presented in Table 1 that all students agreed they took this course as it was one of the compulsory courses the students had to take in the first semester. Second, the students took TOEFL Preparation course to help them improve their English ability in general as one of the goals of having a TOEFL certificate was to state that a person had a sufficient English ability. At last, the TOEFL Preparation course was expected to help the students get a scholarship to continue their study later.

In addition, the result of the interview with the lecturer revealed that the TOEFL Preparation course was provided for students to enable them to have good English proficiency which was then proved by their TOEFL score. The most importantly, this course was provided to facilitate students to achieve the targeted score set by the university. 


\section{Learning Methods}

The finding on the learning methods is demonstrated in Table 2.

Table 2. Learning Methods

\begin{tabular}{clcc}
\hline No. & \multicolumn{1}{c}{ The Way the Students Learn } & \multicolumn{1}{c}{$\begin{array}{c}\text { Percentage } \\
(\mathbf{\%})\end{array}$} & Category \\
\hline 1 & $\begin{array}{l}\text { TOEFL Preparation is taught by } \\
\text { lecturing method. }\end{array}$ & $95.7 \%$ & High \\
2 & $\begin{array}{l}\text { TOEFL Preparation is taught by having } \\
\text { discussion. }\end{array}$ & $94.6 \%$ & High \\
3 & $\begin{array}{l}\text { Providing more samples and more } \\
\text { opportunities to practice doing TOEFL } \\
\text { exercises. } \\
\text { The learning process is teacher- } \\
\text { centered. }\end{array}$ & High \\
\hline
\end{tabular}

Analyzing the learning methods was intended to identify a methodology that appealed to the students and sort of techniques likely to alienate the students in TOEFL Preparation course. Data in this study showed that there were four methods the students wished to be practiced in the TOEFL Preparation course. First, the students preferred to learn TOEFL through lecturing method in which the lecturer explained all the topic in details. At the end of the session, the lecturer and students could discuss the topic in the classroom. Besides, the students expected to have the TOEFL class which provided them more opportunities to do TOEFL exercises so that the students became familiar with the TOEFL test and could applied the strategies they had learned.

The result of the questionnaire was strengthened by the statement given by the lecturer. Based on the interview, the lecturer commented that TOEFL Preparation course would be best taught through one way communication in the classroom. Since the topics are the basic knowledge of English, it was crucial for the lecturer to explain in detail about the topic in oder that students would obtain full comprehension. Later, at the end of the session, both the lecturer and the students could discuss the TOEFL exercise together in the classroom. Based on the data above, it is known that lecturing and discussion were the main methods the students wished to have in the TOEFL Preparation class. They learned better when they listened to the lecturer's explanation to get better understanding about the knowledge. At the end, the students did the exercises and later discussed with the lecturer about the answers.

\section{Available Sources}

The finding on the learning methods is demonstrated in Table 3.

Table 3. Available Sources

\begin{tabular}{clcc}
\hline No. & \multicolumn{1}{c}{ Available Learning Sources } & $\begin{array}{c}\text { Percentage } \\
(\mathbf{\%})\end{array}$ & Category \\
\hline 1 & $\begin{array}{l}\text { Generally, the lecturers possess good } \\
\text { qualifications in TOEFL. }\end{array}$ & $92.9 \%$ & High \\
2 & $\begin{array}{l}\text { The materials are taken from various } \\
\text { sources. }\end{array}$ & $86.1 \%$ & High \\
3 & $\begin{array}{l}\text { The lecturer provides a lot of exercises } \\
\text { to be discussed. }\end{array}$ & $90.4 \%$ & High \\
4 & $\begin{array}{l}\text { The lecturer gives the sample of TOEFL } \\
88.6 \%\end{array}$ & High
\end{tabular}


test questions.

5 The lecturer presents videos and $\quad 86.7 \% \quad$ High pictures when delivering the materials.

This indicator was intended to identify the learning sources available for the students in learning TOEFL Preparation. There were eleven statements included in this part related to the qualified writing lecturers, the materials, and sources provided for the students in Essay Writing course. Among those, five statements were considered crucial since students provided high responses towards the statement. The learning sources in this study refer to the lecturers and learning materials. The results of this study found that the lecturers possessed good qualifications to teach TOEFL which was proven by their TOEFL score which reached a minimum score of 550. Based on Common European Framework of Reference for Language (CEFR), this score is categorized into C1, the highest level in TOEFL.

Related to the materials, the result of this study also revealed that the materials should be various, taken from many related sources so that students had more opportunities to do TOEFL exercises. In addition, the result of the questionnaire also revealed that the lecturer needed to provide various examples of TOEFL test questions and explained in detail the correct answer. By doing so, students would comprehend better. Then, students also wished to attend the TOEFL Preparations class providing various learning media such as videos to make the learning processes more interesting. This means that the learning process should be conducted through various learning media to avoid monotonous learning process.

Furthermore, the interview results indicated that learning sources provided by the university was still limited to one single book. The lecturer admitted that he only focused on one particular book provided by the campus as the main source. This book contains very dense materials, and it is quite difficult to understand what is stated in the book. However, sometimes he provided additional materials which presented the materials in a simpler way.

\section{Students' Characteristics}

The finding about students' characteristics is demonstrated in Table 4.

Table 4. Students' Characteristics

\begin{tabular}{|c|c|c|c|}
\hline No. & Students Characteristics & $\begin{array}{c}\text { Percentage } \\
(\%)\end{array}$ & Category \\
\hline \multicolumn{4}{|c|}{ Students' Ability } \\
\hline 1 & Basic level & $98.9 \%$ & High \\
\hline \multicolumn{4}{|c|}{ Learning Interests } \\
\hline 2 & $\begin{array}{l}\text { The course focuses on TOEFL } \\
\text { strategies. }\end{array}$ & $85.4 \%$ & High \\
\hline 3 & $\begin{array}{l}\text { The course focuses on doing TOEFL } \\
\text { exercises. }\end{array}$ & $100 \%$ & High \\
\hline
\end{tabular}

The data in this part were intended to identify the students' writing ability as well as their interests in learning essay writing. In term of the ability, the data of this study presented that most of the students possessed Basic English proficiency level. These data were laso supported by the TOEFL pre-test score obtained by the researchers. The score represented that most of the students got a score from 380 to 420 , meaning that they were at A2 level based on CEFR. To support this, the result of the interview conducted with the lecturer revealed that most of the students were still at the basic level of English. They were non- 
English Department students who were unfamiliar with English. They even did not have good understanding in the basic skills in English, such basic grammar, vocabulary, and others.

In addition, data from the questionnaire also revealed that the students wished to have the TOEFL Preparation course which emphasized on the TOEFL strategies and exercises. In line with this result, the interview conducted with the lecturer concluded that students needed to be exposed to the TOEFL strategies in order to help them answer the questions. He admitted that the current book used for this course only presented the grammar knowledge which became quite hard for students to understand in a short time. Students needed to be told about the strategies they could applied in answering the TOEFL questions. Thus, the TOEFL strategies was also crucial, in addition to the basic knowledge of English, to help students obtained better understanding about TOEFL. Based on data from the questionnaire and interview, it was concluded that the students need a learning which assisted and provided them with both knowledge and strategies in TOEFL to enable them do the TOEFL test more efficiently.

\section{Setting of the Course}

The finding on the students' characteristics is demonstrated in Table 5.

Table 5. Setting of the Course

\begin{tabular}{|c|c|c|c|}
\hline No. & Setting of the Course & $\begin{array}{c}\text { Percentage } \\
(\%)\end{array}$ & Category \\
\hline \multicolumn{4}{|c|}{ Place } \\
\hline 1 & $\begin{array}{l}\text { The class is comfortable and the } \\
\text { environment supports students to learn } \\
\text { about TOEFL. }\end{array}$ & $84.3 \%$ & High \\
\hline \multicolumn{4}{|c|}{ Time } \\
\hline 2 & More than once a week ( 2 credits each) & $85.4 \%$ & High \\
\hline 3 & Taught for more than one semester & $87.9 \%$ & High \\
\hline
\end{tabular}

The last indicator in needs analysis according to Hutchinson and Waters is the setting of the course. This indicator was intended to identify the best setting where the course takes place. This study revealed that most of the students agreed that the class was comfortable and facilitated them to learn TOEFL. Since this course was conducted online due to the pandemic situation, the classroom means the platform the lecturer used to conduct the class. The TOEFL Preparations course at Universitas Riau was conducted through Zoom meeting or Google Meet, Whatsapp groups, and UPT Bahasa website. The result of the questionnaire was supported by the information obtained from the lecturer stating that the classroom was comfortable and could accommodate all students. In addition to the classroom, she added that the Ministry of Education, Culture, Research, and Technology has provided internet quota for students to attend online classes. Unfortunately, the environment outside did not really support the students to explore their English skills since many students were still less motivated to use English outside the classroom.

In addition, the table shows that most of the students wished to have the TOEFL Preparation class for more than once a week ( 2 credits each meeting). Moreover, the students preferred to attend this course for more than one semester since the topics in TOEFL are cover so many points that it is impossible to discuss them all just in one semester. In line with the result of the questionnaire, the interview results also revealed that the lecturer agreed that the time provided to teach TOEFL Preparation was insufficient. He claimed that TOEFL Preparation course should be taught in 4 credits every meeting for 16 meetings. The TOEFL Preparation course required much time due to the density of the topics that the students should master. Thus, he suggested having Essay Writing in 4 credits each week. 
Data from questionnaire and interview above indicated that the time is becomes a crucial aspect in TOEFL Preparation course. The students were required to have full comprehension about the topics tested in TOEFL to make them able to answer the questions. The result of TOEFL pre-test demonstrated that only few students reached a score above 450 while almost all of them got a score below 450, even below 400. This was due to the condition that they did not have enough time to study all the topics.

Having discussed previously, it was obvious that the TOEFL Preparation course was necessary for university students to build their future career. TOEFL Prediction has a high-stake purpose as in the official TOEFL, which is to determine the students' future (Suryaningsih, 2014) such as their eligibility for undergraduate thesis examination; thus, the students try hard to pass the required minimum test scores. Then, the questionnaire administered to the students and the interview conducted with the lecturer resulted in three main themes: problems, needs, and solution viewing from the students' side, lecturers' side, and the materials. It was discovered that the students needed a new atmosphere in TOEFL Preparation course, a learning process which helped them to be familiar and to have better comprehension about TOEFL materials.

Shanks and the Staff of KAPLAN, as cited in $\mathrm{Vu} \& \mathrm{Vu}$ (2013), stated that the students have to be familiar with the TOEFL test especially when it was the first time the students learning English structure. When asked what made the students still make mistakes, they answered that they needed more time to practice. It should be at least two hours (120 minutes) per meeting, not 100 minutes. A hundred minutes is only enough for a little explaining materials and examples of exercises done by the teacher and a little time for students to do the exercises from the teacher.

Moreover, studying TOEFL does not entail studying the fundamentals of English; rather, it entails knowing how to properly respond to TOEFL exam questions and comprehend specific English texts scientifically. As a result, teachers perceived that they face a difficult problem in dealing with children who have a limited vocabulary. Additionally, when learners lack vocabulary, they focus only on interpreting each word. It is preferable for students to have a working knowledge of basic English skills prior to beginning their TOEFL preparation, as less motivated students who lack basic vocabulary and grammar skills will have difficulty comprehending the succeeding stage of the TOEFL. Regarding these concerns, Yamada (2018) hypothesized that metacognitive tactics for vocabulary learning could aid students prepare for language tests such as the TOEFL. Certain students believe that metacognitive tactics such as expanding their vocabulary beyond what was taught in class can help them enhance their testtaking strategies. Teachers' usual methods were insufficient to improve students' test performance. In other words, this TOEFL preparation class did not ensure that pupils would pass the TOEFL test on their first attempt. Other teachers advocate for the usage of the App and a number of online vocabulary resources as part of their TOEFL preparation program for pre-college EFL students (Al-Johali, 2019).

Inappropriate study times can have a detrimental effect on both teachers and students throughout the teaching-learning process. Prior to beginning the TOEFL preparation program, timing is cited as an ethical consideration (Alderson, \& Hamp-Lyons, 1996; Erfani, 2012). They stated that time constraints can make the lecture tedious or dilute the importance of the ideas they wish to impart. They are frequently weary and take it out on the class by sleeping. When this occurs, the teacher has limited possibility of refocusing the students' attention on the content. They even refuse to participate actively in class. Thus, before to arriving in class, they should plan pleasant strategies for increasing student participation, such as employing games and icebreakers. Additionally, school authorities may have considered class scheduling before to the TOEFL preparation program's launch.

According to the study conducted by ETS - the owner of the TOEFL - to increase 40 points of the TOEFL score, test takers should approximately take 300-hour intensive English program (Shanks \& the Staff of KAPLAN, in Vu, \& Vu, 2013). Duration also should be considered by the teacher as one student complained about the teacher who often came late. However, lateness causes disorganization, distraction, problems in reaching goals, and the failure of life. Thus, the need to redesign the syllabus for TOEFL 
Preparation course was necessary to create better learning process as well as to facilitate students to achieve the targeted score more significantly.

\section{Conclusion}

This study aimed to analyze the needs for TOEFL Preparation course. Through this needs analysis process, the obstacles, and expectations for having an effective learning process could be mapped. Several points found in this study were that the students expected to learn TOEFL through one way teaching or teacher-centered to comprehend the materials better and more thoroughly. Then, they wished to have a learning which allowed them to practice doing the TOEFL exercises more often with the guidance from the lecturer. Thus, the lecturer should provide more sample questions and exercises which allow students to practice doing TOEFL questions so that they could become familiar with the TOEFL questions. Moreover, students admitted that they preferred to learn with various learning media and examples to make the learning process more attractive. In addition, the students wished to obtain the TOEFL strategies from the lecturer to ease them in answering the questions. It was also expected that there would be more available time to have TOEFL Preparation course. The results of this study concluded that the lecturer, and in general the institution, should consider designing a new syllabus which appropriately fulfill the students' needs in TOEFL Preparation course in order that the students' score could increase more significantly.

\section{References}

Al-Johali, K. Y. (2019). Using Mobile Applicatios to Teach Vocabulary: Saudi EFL Teachers' Perceptions. Global Journal of Foreign Language Teaching, 9(1), 51-68.

Alderson, J. C., \& Hamp-Lyons, L. (1996). TOEFL Preparation Courses: A Study of Washback. Language Testing, 13(3), 280-297.

Ananda, R. (2016). Problems with Section Two ITP TOEFL Test. Studies in English Language and Education, 3(1), 37-45.

Bosher, S., \& Smalkoski, K. (2002). From needs analysis to curriculum development: Designing a course in health- care communication for immigrant students in the USA. English for Specific Purposes, 21(3), 59-79.

Brown, H. D. (2001). Teaching by principles: An interactive approach to language pedagogy. Pearson Education Inc.

Brown, H. D. (2004). Language Assessment: Principles and Classroom Practice. Pearson Education Inc.

Chaudron, C., Doughty, C., Kim, Y., Kong, D. Lee, J., Lee, Y., Long, M., Rivers, R., \& Urano, K. (2005). A task- based needs analysis of a tertiary Korean as a foreign language program. In M. Long (Ed.), Second language needs analysis (pp. 225-261). Cambridge University Press.

Crystal, D. (2003). English as a Global Language. Cambridge University Press.

Educational Testing Service (ETS). (2019a). Test Content. http://www.ets.org/toefl_itp/content

Educational Testing Service (ETS). (2019b). The TOEFL test. http://www.ets.org/toefl

Erfani, S. S. (2012). A Comparative Washback Study of IELTS and TOEFL iBT on Teaching and Learning Activities in Preparation Courses in the Iranian Context. English Language Teaching, 5(8), 
$185-195$.

Ermawan, E., Arifin, Z., \& Salam. U. (2014). An Analysis on Graduates' Perception toward Test of English as a Foreign Language. Jurnal Pendidikan Dan Pembelajaran, 3(10).

Graves, K. (2004). Designing Language Courses: A Guide for Teachers. Heinle \& Heinle.

Hambali, M. (2008). Shortcut Strategies in Analyzing Sentence Structures in TOEFL. Lingua: Jurnal Bahasa Dan Sastra, 9(2), 82-88.

Hutchinson, T., \& Waters, A. (1987). English for Specific Purposes. Cambridge University Press.

Liu, O. L. (2014). Investigating the Relationship between Test Preparation and TOEFL iBT Performance.

Ma, J., \& Cheng, L. (2015). Chinese Students' Perceptions of the value of Test Preparation Courses for the TOEFL iBT: Merit, Worth, and Significance. TESL Canada Journal, 33(1), 58-79.

Mahmud, M. (2014). The EFL Students' Problems in Answering the Test of English as a Foreign Language (TOEFL): A Study in Indonesian Context. Theory and Practice in Language Studies, 4(12), 2581-2587.

Masfufah, S. (2018). Indonesian College Students' Perceptions of TOEFL Preparation Class. EduLite: Journal of English Education, Literature, and Culture, 3(1), 66-78.

Nation, I. S. P., \& Macalister, J. (2010). Language Curriculum Design. Routledge.

Netta, A., \& Trisnawati, I. K. (2019). Acehnese Undergraduate Students' Strategies in Preparing for TOEFL Prediction: A Preliminary Study. Englisia, 7(1), 41-52.

Ng, J. N. K. (2007). Test of English as a Foreign Language (TOEFL): Good Indicator for Students' Success at Community Colleges? Oregon State University, Oregon.

Nunan, D. (1989). Designing Tasks for the Communicative Classroom. Cambridge University Press.

Richards, J. C. (2001). Curriculum Development in Language Teaching. Cambridge University Press.

Roberts, M. (2000). An Examination of the Way a Group of Korean Language Learners Prepare for the Test of English as a Foreign Language (TOEFL). University of Toronto, Toronto.

Samad, I. A., Jannah, M. \& Fitriani, S. S. (2017). EFL Students' Strategies Dealing with Common Difficulties in TOEFL Reading Comprehension Section. International Journal of Language and Education, 1(1), 29-36.

Stricker, L. J., \& Attali, Y. (2010). est takers' attitudes about the TOEFL iBT ${ }^{\mathrm{TM}}$. ETS Research Report Series, 1 .

Sudjana, N. (2002). Metoda Statistika. Tarsito.

Sudrajat, W. N. A., \& Astuti, E. R. (2018). Students' Perceptions of the Use of TOEFL Preparation Online Course on the Test Performance: The Case of TOEFL Structure and Written Expression Test. Humaniora, 9(3), 275-282. 
Suryaningsih, H. (2014). Students' Perceptions of International English Language Testing System (IELTS) and Test of English as a Foreign Language (TOEFL) Test. Indiana University of Pennsylvania.

Vu, L. T., \& Vu, P. H. (2013). Is the TOEFL Score Reliable Indicator of International Graduate Students' Academic Achievement in America Higher Education? International Journal on Studies in English Language and Literature, 1(1), 11-19.

Wainer, H. \& Lukhele, R. (1997). How reliable is the TOEFL test? (TOEFL Tech). Educational Testing Service.

Webster, M. (2017). Test.

Yamada, H. (2018). Exploring the Effects of Metacognitive Strategies on Vocabulary Learning of Japanese junior High School Students. The Journal of Asia TEFL, 15(4), 931-944.

Zucker, S. (2003). Fundamentals of Standardized Testing (Research Report). 